\title{
APAKAH FENOMENA FLYPAPER EFFECT ASIMETRIS TERJADI PADA KEBIJAKAN BELANJA PEMERINTAH DAERAH?
}

\author{
Adhipradana P. Swasito \\ Politeknik Keuangan Negara STAN
}

Alamat Korespondensi: adhipradana.ps@pknstan.ac.id

\section{INFORMASI ARTIKEL}

Diterima Pertama

[19 07 2021]

Dinyatakan Diterima

[25 07 2021]

KATA KUNCI:

flypaper effect, belanja publik, DAU, DAK, PAD

KLASIFIKASI JEL: $\mathrm{H} 60, \mathrm{H} 72$

\section{ABSTRACT}

Fluctuation in local government revenue will shift local government spending. This study aims to identify and analyze the response of local government spending policies to an increase or decrease in transfer funds from the central government (Balance Fund) and local own revenue (known as Pendapatan Asli Daerah). The study utilizes data from provincial governments throughout Indonesia for the 2010-2019 period. This study finds that local government spending policies are more responsive to increases or decreases in local government revenues in the form of DAU, meaning that there is a flypaper effect phenomenon. In addition, this study also found that the decline in DAU also caused a contraction in public spending, which means that there is no asymmetrical flypaper effect.

\section{ABSTRAK}

Kenaikan atau penurunan pendapatan pemerintah daerah akan meningkatkan atau menurunkan belanja pemerintah daerah Tujuan dari penelitian ini adalah untuk mengidentifikasi dan menganalisis respons kebijakan belanja pemerintah daerah terhadap kenaikan atau penurunan dana transfer dari pemerintah pusat (Dana Perimbangan) dan Pendapatan Asli Daerah. Penelitian menggunakan uji regresi untuk menganalisis data keuangan seluruh pemerintah provinsi di Indonesia selama rentang periode 2010-2019 yang dipublikasikan oleh Badan Pusat Statistik. Penelitian ini menemukan bahwa kebijakan belanja pemerintah daerah lebih responsif terhadap kenaikan atau penurunan penerimaan daerah berupa DAU, artinya ada fenomena flypaper effect pada kebijakan belanja publik di Indonesia. Selain itu, penelitian ini juga menemukan bahwa penurunan penerimaan daerah berupa DAU juga menyebabkan kontraksi pada belanja publik, yang artinya flypaper effect yang ada tidak bersifat asimetris. 


\section{PENDAHULUAN}

Prediksi bahwa kenaikan pendapatan pemerintah daerah akan meningkatkan belanja pemerintah daerah merupakan suatu pemikiran yang logis. Namun demikian, perlu dipahami bahwa pendapatan pemerintah daerah didapat dari berbagai sumber. Penelitian mengenai dampak dari berbagai sumber pendapatan daerah terhadap belanja pemerintah daerah telah menjadi fokus penelitian selama beberapa dekade terakhir. Salah satu pionir penelitian di bidang ini menyimpulkan bahwa kenaikan belanja pemerintah daerah lebih elastis terhadap dana transfer dari pemerintah pusat jika dibandingkan dengan sumber pendapatan daerah yang lain (Bradford \& Oates, 1971). Literatur keuangan publik kemudian mulai menyebut fenomena ini dengan nama fenomena flypaper effect $^{1}$ (Courant, Gramlich, \& Rubinfeld, 1978). Saat ini, flypaper effect mungkin merupakan salah satu fenomena yang paling banyak didokumentasikan dalam literatur federalisme fiskal. Meskipun mayoritas menyatakan bahwa pengeluaran publik lebih responsif terhadap kenaikan dana transfer dari pemerintah pusat daripada pendapatan lain (misalnya pendapatan pajak), hasil dari beberapa penelitian masih belum mencapai konsensus.

Hal berikutnya yang menjadi perhatian para peneliti adalah fakta bahwa jumlah pendapatan daerah, baik berupa dana transfer dari pemerintah pusat kepada pemerintah daerah ataupun penerimaan asli daerah, bisa meningkat atau berkurang. Jika pemerintah daerah merespons kenaikan atau penurunan sumber pendapatan daerah dengan kebijakan belanja publik yang searah maka fenomena ini disebut dengan flypaper effect simetris. Jika arah kebijakan belanja publik berlawanan dengan kenaikan atau penurunan sumber pendapatan daerah, maka hal ini disebut dengan flypaper effect yang asimetris (Gamkhar, 2000). Penelitian-penelitian pionir mengenai adanya flypaper effect yang asimetris telah membuka lahan diskusi yang baru mengenai fenomena ini. Tetapi, meskipun telah banyak terdapat bukti empiris mengenai adanya respons belanja publik yang asimetris, penelitian di bidang ini masih layak untuk terus dilakukan agar dapat diketahui penjelasan yang konklusif mengenai fenomena flypaper effect yang asimetris (Heyndels, 2001).

Dalam konteks kebijakan belanja publik di Indonesia, fenomena flypaper effect juga sudah dikaji dalam banyak literatur. Kuncoro (2007) mengkaji pengaruh dana transfer pada kinerja fiskal pemerintah daerah kota dan kabupaten. Penelitian tersebut menyimpulkan bahwa penerimaan berupa dana transfer dari pemerintah pusat menstimulasi peningkatan belanja pemerintah daerah yang lebih besar dari pada pendapatan asli daerah. Penelitian lain yang menggunakan data pemerintah kota dan kabupaten dilakukan oleh Amalia (2017) dan Inayati \& Setiawan (2018). Dengan menggunakan sampel data yang lebih mutakhir dibanding penelitian oleh Kuncoro (2007), kedua penelitian ini menghasilkan kesimpulan yang serupa yaitu dana transfer dari pemerintah pusat dan pendapatan asli daerah berpengaruh terhadap belanja daerah.

Kemudian, beberapa penelitian juga mengangkat tema flypaper effect dengan menggunakan data level provinsi. Menggunakan data level provinsi tahun 2016-2018, Fadilah \& Helmayunita (2020) menemukan bahwa Dana Alokasi Khusus (DAK) tidak berpengaruh terhadap besaran belanja pemerintah daerah. Sementara itu, menggunakan data level provinsi periode 2013-2018 Utami \& Iskandar (2020) justru menyimpulkan bahwa tidak ada fenomena flypaper effect pada kinerja belanja pemerintah provinsi. Selain penelitian-penelitian yang telah disebutkan masih banyak lagi penelitian-penelitian mengenai fenomena flypaper effect pada belanja pemerintah per provinsi (lihat Fikri, 2020; Rudi, 2018; Yacoub \& Lestari, 2019).

Dari penelitian-penelitian yang telah disebutkan, ada dua hal yang perlu diperhatikan. Pertama, mayoritas dari penelitian-penelitian tersebut umumnya menggunakan model sederhana tanpa adanya variabel kontrol. Kedua, belum ada yang meneliti mengenai arah respons dari kebijakan belanja publik apabila terjadi penurunan pada sumber-sumber penerimaan daerah. Untuk mengisi celah penelitian tersebut, penelitian ini bertujuan untuk menganalisis secara empiris apakah respons kebijakan belanja pemerintah dipengaruhi oleh sumber-sumber pendapatan daerah secara simetris atau asimetris.

Dengan demikian, penelitian ini berkontribusi dalam dua aspek. Dari aspek kemutakhiran data, penelitian ini mengoptimalkan penggunaan data level provinsi rentang periode 2010-2019. Rentang data ini menyajikan bukti empiris terbaru di Indonesia. Untuk data tahun 2020, meskipun tersedia, kami tidak mengikutsertakan data tahun 2020 mengingat anomali data akibat pandemi Covid19 yang muncul di triwulan I 2020. Dari aspek

\footnotetext{
${ }^{1}$ Flypaper effect dapat diterjemahkan secara kata per kata menjadi efek kertas terbang. Namun demikian hal tersebut tidak umum dilakukan pada berbagai penelitian sebelumnya. Sehingga dalam artikel ini frasa flypaper effect akan tetap disajikan menggunakan bahasa asing.
} 
keterbaharuan, penelitian ini berkontribusi dalam menyajikan bukti awal mengenai arah respons kebijakan belanja pemerintah daerah di Indonesia sehubungan dengan kenaikan atau penurunan dana transfer dari pemerintah pusat.

Penelitian ini disusun sebagai berikut: Pada bagian selanjutnya, akan disajikan literatur yang berhubungan dengan fenomena flypaper effect. Kemudian, penelitian ini akan menyajikan strategi penelitian yang akan digunakan untuk mencapai tujuan penelitian serta menguraikan data yang digunakan. Setelah itu, akan disajikan hasil dan pembahasan atas hasil uji regresi. Kesimpulan terhadap seluruh hasil penelitian akan dipaparkan pada bagian akhir dari studi ini.

\section{KERANGKA TEORI DAN PENGEMBANGAN HIPOTESIS}

Secara umum, studi mengenai flypaper effect berusaha untuk memahami fenomena yang terjadi pada kebijakan belanja publik ketika sumber pendapatan berfluktuasi. Bailey \& Connolly (1998) menyampaikan bahwa salah satu pendapat dalam Traditional Theory of Grants-in-aid adalah dana alokasi yang diberikan secara lump-sum, baik unconditional grants (dapat disetarakan dengan Dana Alokasi Umum di Indonesia) maupun conditional grants (dapat disetarakan dengan Dana Alokasi Umum di Indonesia), memiliki dampak yang sama besar terhadap kebijakan pengeluaran pemerintah daerah. Namun demikian, secara empiris ditemukan bahwa kenaikan satu unit dana transfer dari pemerintah pusat menstimulasi pengeluaran publik yang jauh lebih besar dari pada kenaikan satu unit pada sumber pendapatan yang lain (Inman, 2016).

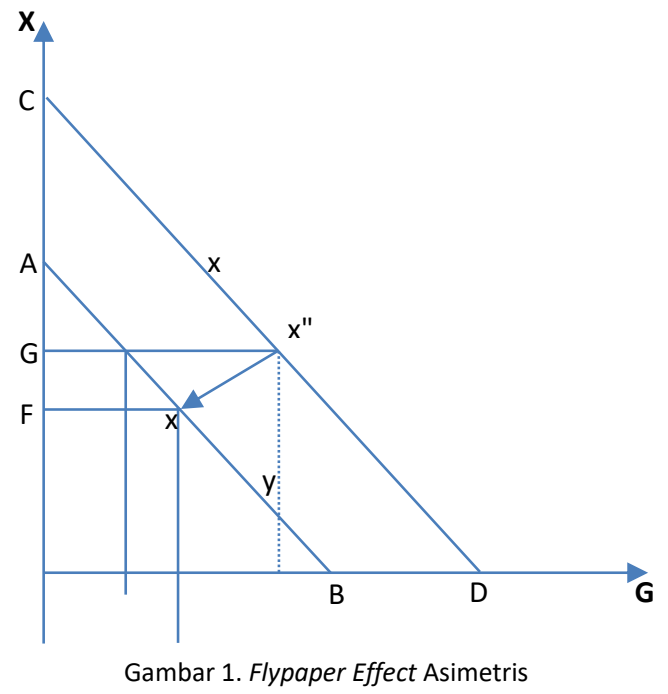

Berbagai jenis reaksi belanja publik terhadap perubahan pendapatan pemerintah dapat diilustrasikan pada Gambar 1, yang merangkum pilihan belanja masyarakat secara keseluruhan antara belanja swasta (X) dan belanja publik (G). Untuk membuat model yang lebih sederhana, anggaran pemerintah daerah hanya diilustrasikan terdiri dari dua bagian: pendapatan asli daerah dan dana transfer yang diperoleh dari tingkat pemerintah yang lebih tinggi. Melalui perpajakan, pemerintah daerah dapat menggunakan sebagian pendapatan masyarakat untuk membiayai pengeluaran publik.

Flypaper effect mengacu pada keadaan yang menunjukkan pemerintah daerah dapat merespons perubahan batasan anggaran (budget constraint) secara berbeda, tergantung penyebab perubahan batasan anggaran: karena perubahan pendapatan masyarakat (yang dikenakan pajak) atau pendapatan dari dana transfer pemerintah pusat. Mengacu pada ilustrasi pada Gambar 1, asumsikan jika garis anggaran pemerintah daerah bergeser dari garis $A B$ (pilihan konsumsi ada pada titik $\mathrm{x}$ ) ke garis CD. Pergeseran ini dapat dijelaskan melalui dua alternatif. Pertama, jika pergeseran ini disebabkan oleh penambahan pendapatan masyarakat (dan juga menyebabkan kenaikan pendapatan pajak daerah), maka titik optimum masyarakat akan bergeser ke titik $x^{\prime}$. Baik pengeluaran privat maupun pengeluaran publik meningkat, namun pengeluaran privat lebih besar. Kedua, jika pergeseran ke garis anggaran CD disebabkan oleh kenaikan dana transfer dari pemerintah pusat, fenomena flypaper effect akan menunjukkan perubahan titik optimum ke $x^{\prime \prime}$. Hal ini menjelaskan bahwa pengeluaran publik lebih responsif terhadap kenaikan dana transfer dari pemerintah pusat daripada perubahan pendapatan privat.

Hamilton (1986) menjelaskan adanya fenomena flypaper effect menggunakan Teori Deadweight Loss. Hamilton (1986) berpendapat bahwa dana transfer dari pemerintah pusat tidak menciptakan deadweight loss sebagaimana penerimaan pajak daerah. Sehingga, pemerintah lebih responsif dalam membelanjakan dana transfer dari pemerintah pusat daripada membelanjakan dana yang bersumber dari pajak daerah. Meskipun demikian, Hines \& Thaler (1995) menolak penjelasan teori ini karena mereka berpendapat bahwa deadweight loss dari pajak daerah hanya bersifat marginal. Sehingga tidak bisa menjelaskan perbedaan pengaruh dana transfer dari pemerintah pusat dan pajak daerah terhadap kebijakan belanja pemerintah daerah.

Dari sudut pandang ekonomi politik, McGuire (1975) memunculkan pendapat bahwa fenomena flypaper effect muncul karena kebijakan para politisi. McGuire (1975) berasumsi bahwa umumnya politisi akan membelanjakan seluruh dana publik yang mereka miliki untuk menjaga popularitas politik dan tingkat elektabilitas. Berapa pun dana yang tersedia, politisi akan menghabiskannya pada belanja publik untuk membuat para pemilih merasa tidak dirugikan. Dan sebagian politisi menganggap bahwa dana 
transfer lebih "murah" secara politis dibanding sumber pendapatan berupa pajak daerah. Bailey \& Connolly (1998) dan Inman (2016) juga berpendapat bahwa konsep ekonomi politik merupakan konsep yang paling dapat menjelaskan fenomena flypaper effect secara komprehensif.

Literatur-literatur yang menjelaskan mengenai respons simetris belanja daerah terhadap pendapatan daerah bermunculan pada awal tahun 1960-an. Namun demikian, pemikiran baru muncul pada tahun 1980-an. Yaitu ketika beberapa negara demokrasi barat berusaha untuk mengontrol defisit anggaran mereka. Pada masa tersebut, pemerintah federal mengurangi secara signifikan jumlah transfer kepada pemerintah daerah. Gramlich (1987) menyajikan bukti pertama yang menunjukkan bahwa kebijakan belanja publik dapat merespons penurunan dana transfer secara asimetris. Bukti ini kemudian ditinjau ulang lagi oleh Stine (1994) dan Gamkhar \& Oates (1996) dan menghasilkan kesimpulan yang berbeda mengenai adanya respons asimetris kebijakan belanja publik terhadap penurunan dana transfer dari pemerintah federal di Amerika Serikat.

Respons kebijakan belanja publik yang asimetris juga dapat dijelaskan menggunakan ilustrasi pada Gambar 1. Jika garis anggaran CD bergeser kembali ke garis $A B$, maka seharusnya (jika menggunakan konsep respons simetris) titik optimum akan kembali ke titik x. Artinya belanja publik menurun ke titik optimum sebelumnya. (McGuire, 1975) menyatakan bahwa hal ini bertentangan dengan apa yang akan dilakukan oleh para politisi karena mereka tidak mau membuat masyarakatnya (terutama para pemilihnya) merasa dirugikan. Sebisa mungkin, mereka akan berusaha mengembalikan belanja publik ke titik y dengan cara mengoptimalkan dana publik yang ada dan menaikkan pendapatan yang berasal dari pajak daerah.

Penelitian-penelitian di Indonesia umumnya menemukan bahwa dana transfer dari pemerintah pusat berupa Dana Alokasi Umum (DAU), Dana Alokasi Khusus (DAK) yang umumnya disebut dengan Dana Perimbangan serta Pendapatan Asli Daerah (PAD) berpengaruh secara positif dan signifikan terhadap kebijakan belanja publik (untuk penelitianpenelitian terbaru lihat Fikri (2020) dan Utami \& Iskandar (2020). Selain itu, umumnya penelitianpenelitian di Indonesia juga menemukan bahwa kebijakan belanja pemerintah daerah lebih responsif terhadap Dana Perimbangan dibanding terhadap PAD (untuk penelitian-penelitian terbaru lihat Fadilah \& Helmayunita, 2020; Inayati \& Setiawan, 2018). Dari hasil penelusuran, kami juga menemukan masih minimnya penelitian yang membahas mengenai arah respons kebijakan belanja publik terhadap penurunan sumber penerimaan daerah.
Untuk memperkaya literatur yang sudah ada, penelitian ini akan menguji beberapa hipotesis:

Hipotesis 1: Sumber pendapatan daerah berpengaruh secara signifikan terhadap kebijakan belanja publik daerah.

Hipotesis 2: Belanja pemerintah daerah lebih responsif terhadap kenaikan atau penurunan dana transfer dari pemerintah pusat daripada pendapatan asli daerah.

Hipotesis ini berusaha untuk menunjukkan pengaruh dari penerimaan daerah berupa dana transfer dari pemerintah pusat dan juga PAD terhadap kebijakan belanja pemerintah daerah. Selain itu hipotesis ini juga ingin memperkuat bukti empiris yang ada yang menyatakan bahwa dana transfer dari pemerintah pusat lebih mempengaruhi kebijakan belanja publik dibanding dengan PAD. Diterimanya hipotesis ini menandakan masih besarnya ketergantungan pemerintah daerah terhadap dana transfer dari pemerintah pusat.

Hipotesis 3: Penurunan pendapatan daerah berupa dana transfer dari pemerintah pusat akan menyebabkan penurunan belanja publik.

\section{METODE PENELITIAN}

Untuk menguji hipotesis yang telah dirumuskan, penelitian ini pertama-tama menggunakan model sederhana sebagaimana diajukan oleh Kang \& Setyawan (2012) dan Solikin (2016). Ada dua alasan yang melandasi penggunaan model yang telah mereka kembangkan. Pertama, dua penelitian ini juga mengoptimalkan data secara nasional, sehingga analogi yang sama dapat digunakan sebagai justifikasi atas penggunaan model tersebut pada penelitian ini. Kedua, penelitian oleh Kang \& Setyawan (2012) dan Solikin (2016) menggunakan data periode 2001-2008 dan periode 2012-2013. Dengan menggunakan model tersebut untuk kumpulan data yang lebih mutakhir, penelitian ini berharap untuk dapat memperbaharui literatur yang ada.

Model yang paling sederhana, sebagaimana digunakan Kang \& Setyawan (2012) hanya menyertakan total dana transfer yang diterima oleh pemerintah daerah dan total pendapatan asli daerah sebagai variabel bebas. Persamaan dari model ini dapat diilustrasikan sebagai berikut:

$$
\begin{aligned}
\exp _{i, t}= & \beta_{0, i}+\beta_{1} \operatorname{trans}_{i, t}+\beta_{2} o w n_{i, t} \\
& +u_{i, t}
\end{aligned}
$$

Variabel $\exp _{i, t}$ adalah jumlah belanja pemerintah daerah $i$ pada tahun $t$. Sementara itu variabel $\operatorname{trans} f_{i, t}$ dan $o w n_{i, t}$ secara berturut-turut mewakili Dana Perimbangan dan Pendapatan Asli Daerah. Karena unsur variabel penjelas yang sangat sedikit, kami berpendapat bahwa persamaan (1) 
belum dapat menjelaskan secara detail mengenai fenomena flypaper effect.

Oleh karena itu, penelitian ini memodifikasi persamaan yang digunakan dalam Solikin (2016). Namun, alih-alih menggunakan variabel Sisa Lebih Penghitungan Anggaran (SILPA), penelitian ini akan lebih menitikberatkan pada hubungan antara DAU, DAK, dan PAD. Dengan demikian kondisi $\beta_{1}>$ $\beta_{3}$ pada model (2) mengindikasikan adanya flypaper effect. Selain variabel DAU, DAK dan PAD, berbeda dengan penelitian dalam Solikin (2016), penelitian ini juga menyertakan demografi penduduk sebagai variabel kontrol.

$$
\begin{aligned}
\exp _{i, t}= & \beta_{0, i}+\beta_{1} \operatorname{dau}_{i, t}+\beta_{2} \operatorname{dak}_{i, t} \\
& +\beta_{3} \text { pad }_{i, t} \\
& +\boldsymbol{\theta}^{\prime}{ }_{i, j} \text { controls }_{i, t}+u_{i, t}
\end{aligned}
$$

Variabel kontrol ini dimasukkan karena literatur menunjukkan bahwa variabel-variabel tersebut berpotensi mempengaruhi belanja pemerintah. Data demografi penduduk yang diikutsertakan dalam vektor controls cod $_{i, t}$ adalah kepadatan penduduk (popdens) dan proporsi penduduk non-usia kerja berupa: young (untuk penduduk 0-15 tahun) dan elder (untuk penduduk diatas 65 tahun). Variabel demografi penduduk ini digunakan untuk melihat volatilitas pengeluaran publik terhadap guncangan ekonomi (Furceri \& Karras, 2008) serta untuk menangkap karakteristik provinsi yang mungkin mempengaruhi kebijakan belanja (Albuquerque, 2011).

Model 3 kemudian dikembangkan untuk menguji Hipotesis 3. Untuk menginvestigasi arah respons kebijakan pengeluaran pemerintah daerah terkait perubahan pada penerimaan dana transfer dari pemerintah pusat, penelitian ini menggunakan konsep yang dikembangkan oleh (Gamkhar \& Oates, 1996) dan (Heyndels, 2001). Konsep mereka yaitu memperkenalkan variabel dummy dan juga interaksinya dengan pertumbuhan pendapatan daerah.

$$
\begin{aligned}
\exp _{i, t}= & \beta_{0, i}+\beta_{1} \operatorname{dau}_{i, t}+\beta_{2} \operatorname{dak}_{i, t} \\
& +\beta_{3} \operatorname{tax}_{i, t}+\beta_{4} d_{1}\left(\text { dau }_{t}-\text { dau }_{t-1}\right) \\
& +\boldsymbol{\theta}^{\prime}{ }_{i, t} \boldsymbol{c o n t r o l s}_{i, t}+u_{i, t}
\end{aligned}
$$

Persamaan (3) menyertakan interaksi antara variabel dummy $d_{1}$ dengan variabel pertumbuhan penerimaan DAU $\left(d a u_{t}-d a u_{t-1}\right)$. Variabel $d_{1}$ bernilai 1 jika $\left(d a u_{t}-d a u_{t-1}\right)<0$, dan bernilai 0 jika selainnya. Berbeda dengan penelitian sebelumnya, konsep ini digunakan oleh Gamkhar \& Oates, (1996) untuk menghitung data agregat Amerika Serikat, sedangkan Heyndels (2001) menggunakannya untuk melihat flypaper effect asimetris pada salah satu provinsi di benua Eropa.

Data yang digunakan dalam penelitian ini merupakan data pemerintah daerah se-Indonesia yang sudah dipublikasikan oleh Badan Pusat Statistik.
Berbeda dengan data yang digunakan dalam penelitian oleh Kang \& Setyawan (2012) dan Solikin (2016) penelitian ini menggunakan data seluruh provinsi di Indonesia dari tahun 2010 sampai dengan tahun 2019. Data level provinsi digunakan karena alasan ketersediaan data.

\section{HASIL PENELITIAN}

Untuk menguji hipotesis yang telah dirumuskan, pertama-tama penelitian ini mengestimasi koefisien pada model menggunakan PLS (pooled least square) meskipun estimator yang dihasilkan diprediksi tidak konsisten. Untuk menghasilkan estimator yang lebih dapat diandalkan, penelitian ini kemudian menggunakan fixed effects (FE) dan random effects (RE). Lalu uji Hausman dilakukan untuk menyimpulkan estimator yang paling konsisten. Uji Hausman untuk setiap model menunjukkan bahwa estimasi menggunakan FE lebih

\begin{tabular}{|c|c|c|c|}
\hline VARIABLES & $\begin{array}{l}\text { (1) } \\
\text { PLS }\end{array}$ & $\begin{array}{l}(2) \\
\mathrm{FE}\end{array}$ & $\begin{array}{l}\text { (3) } \\
R E\end{array}$ \\
\hline transf & $\begin{array}{l}0.431 * \star * \\
(0.0895)\end{array}$ & $\begin{array}{c}0.618 * * * \\
(0.101)\end{array}$ & $\begin{array}{l}0.599 * * * \\
(0.0993)\end{array}$ \\
\hline own & $\begin{array}{l}1.839 * * * \\
(0.0410)\end{array}$ & $\begin{array}{l}1.669 * * * \\
(0.0294)\end{array}$ & $\begin{array}{l}1.698 * * * \\
(0.0225)\end{array}$ \\
\hline Constant & $\begin{array}{l}1.7 e+09 * \star \star \\
(1.69 e+08)\end{array}$ & $\begin{array}{l}1.8 e+09 * \star \star \\
(1.44 e+08)\end{array}$ & $\begin{array}{l}1.8 e+09 * * * \\
(4.27 e+08)\end{array}$ \\
\hline $\begin{array}{l}\text { Obs } \\
\text { R-squared } \\
\text { No.of grup }\end{array}$ & $\begin{array}{c}340 \\
0.943\end{array}$ & $\begin{array}{c}340 \\
0.932 \\
34\end{array}$ & 340 \\
\hline
\end{tabular}
dipilih, namun agar dapat memberikan gambaran secara lebih jelas seluruh hasil estimasi akan kami sajikan.

\subsection{Model 1}

Tabel 1. Hasil uji Model (1)

Hasil uji Model 1 menunjukkan hasil yang signifikan dan robust untuk semua variabel dan untuk setiap cara estimasi. Hal ini menunjukkan bahwa model yang disusun merupakan model yang konsisten (Sacchi \& Salotti, 2017). Selain itu, koefisien estimasi Dana Perimbangan dan PAD berpengaruh secara signifikan dan positif terhadap kebijakan belanja publik. Hasil ini mengkonfirmasi Hipotesis 1 yang diajukan pada bagian sebelumnya.

Dapat diperhatikan pula ternyata uji terhadap Model 1 menghasilkan koefisien determinasi $\left(R^{2}\right)$ sangat tinggi. Hal ini terlihat wajar mengingat Dana Perimbangan dan PAD merupakan dua komponen utama yang digunakan oleh pemerintah daerah untuk membiayai belanja publik. Selain itu, angka koefisien determinasi juga menunjukkan bahwa model sederhana ini ternyata sudah mampu menjelaskan sekitar 93\% dari fluktuasi belanja pemerintah daerah. 
Serupa dengan penelitian oleh Kang \& Setyawan (2012), penelitian ini juga menunjukkan bahwa pendapatan pajak daerah lebih mempengaruhi besarnya belanja pemerintah daerah dibandingkan dengan jumlah Dana Perimbangan. ${ }^{2}$ Berdasarkan model sederhana ini, Kang \& Setyawan (2012) menyampaikan gagasan bahwa secara empiris tidak terdapat fenomena flypaper effect pada kebijakan belanja publik. Sehingga dalam penelitian mereka, disimpulkan bahwa kebijakan belanja pemerintah daerah lebih responsif terhadap fluktuasi Pendapatan Asli Daerah daripada Dana Perimbangan.

Namun demikian, hasil uji Model 1 serta gagasan yang disajikan oleh (Kang \& Setyawan, 2012) dapat disempurnakan jika kita menyajikan variabel secara lebih detail. Hasil uji pada Model 1 masih menimbulkan pertanyaan: apakah ada perbedaan antara pengaruh Dana Alokasi Umum dan Dana Alokasi Khusus, sebagai unsur penyusun Dana Perimbangan, terhadap belanja pemerintah daerah? Agar bukti empiris yang disajikan lebih mendalam, maka variabel Dana Perimbangan dapat dipecah menjadi Dana Alokasi Umum dan Dana Alokasi Khusus.

\subsection{Model 2}

Tabel 2. Hasil uji Model 2

\begin{tabular}{|c|c|c|c|}
\hline VARIABLES & $\begin{array}{l}(1) \\
\text { PLS }\end{array}$ & $\begin{array}{l}(2) \\
\mathrm{FE}\end{array}$ & $\begin{array}{l}\text { (3) } \\
\mathrm{RE}\end{array}$ \\
\hline dau & $\begin{array}{c}3.107 * \star \star \\
(0.416)\end{array}$ & $\begin{array}{c}2.384 * \star \star \\
(0.425)\end{array}$ & $\begin{array}{c}2.466 * \star \star \\
(0.411)\end{array}$ \\
\hline dak & $\begin{array}{l}-0.215 \\
(0.134)\end{array}$ & $\begin{array}{l}0.0427 \\
(0.107)\end{array}$ & $\begin{array}{c}0.0441 \\
(0.108)\end{array}$ \\
\hline pad & $\begin{array}{l}1.685 * * * \\
(0.0628)\end{array}$ & $\begin{array}{l}1.801 * * \star \\
(0.0894)\end{array}$ & $\begin{array}{l}1.721 * \star \star \\
(0.0360)\end{array}$ \\
\hline popdens & $\begin{array}{c}548,522 * * * \\
(116,920)\end{array}$ & $\begin{array}{l}425,906 * \\
(71,506)\end{array}$ & $\begin{array}{c}446,713 * * * \\
(72,902)\end{array}$ \\
\hline young & $\begin{array}{l}2.044 e+09 \\
(1.37 e+09)\end{array}$ & $\begin{array}{c}7.755 e+08 \\
(8.46 e+08)\end{array}$ & $\begin{array}{l}1.051 e+09 \\
(9.83 e+08)\end{array}$ \\
\hline elder & $\begin{array}{c}-6.4 e+10 * \star \\
(8.54 e+09)\end{array}$ & $\begin{array}{l}-6.96 e+10 \\
(5.32 e+10)\end{array}$ & $\begin{array}{c}-6.7 e+10 \\
(2.74 e+10)\end{array}$ \\
\hline Constant & $\begin{array}{l}1.44 e+09 * * \\
(7.17 e+08)\end{array}$ & $\begin{array}{l}3.674 e+09 * \\
(2.47 e+09)\end{array}$ & $\begin{array}{l}2.385 e+09 * \\
(1.25 e+09)\end{array}$ \\
\hline $\begin{array}{l}\text { Obs } \\
\text { R-squared } \\
N\end{array}$ & $\begin{array}{c}336 \\
0.962\end{array}$ & $\begin{array}{c}336 \\
0.946 \\
34\end{array}$ & 336 \\
\hline
\end{tabular}

Tabel 2 menyajikan hasil estimasi untuk Model 2. Sekali lagi, koefisien determinan yang dihasilkan oleh model sudah sangat baik (dengan $\mathrm{R}^{2}$ sebesar $\pm 94 \%$ ) dan sebagian besar koefisiennya berbeda secara signifikan dari nol. Karena uji Hausman menunjukkan hasil dari FE lebih dipilih daripada RE, hal ini menunjukkan bahwa Tabel 2 paling baik dapat dijelaskan dengan model yang menjelaskan intersep spesifik per provinsi. Dengan alasan itu, pada bagian ini kami juga hanya akan memusatkan diskusi kami menggunakan hasil FE. Namun, dapat kita perhatikan juga, bahwa hasil yang disajikan oleh FE dan RE pada Tabel 2 tidaklah berbeda jauh.

Tabel 2 menunjukkan bahwa variabel dau dan pad berpengaruh secara positif dan signifikan terhadap belanja pemerintah daerah. Artinya, semakin besar penerimaan daerah berupa DAU dan Pendapatan Asli Daerah, akan direspons dengan bertambah besarnya belanja pemerintah daerah. Namun demikian, Tabel 2 menyajikan bahwa variabel dak tidak signifikan terhadap besaran belanja pemerintah provinsi di Indonesia. Salah satu alternatif penjelasan mengenai hal ini mengacu pada karakteristik DAK yang bukan ditujukan untuk belanja rutin pemerintah daerah. DAK, sebagaimana namanya, memiliki sifat khusus. Artinya DAK hanya dialokasikan untuk pengeluaran tertentu saja, dan jumlahnya relatif lebih sedikit dibandingkan dengan DAU. Sementara itu dari tiga variabel kontrol yang diikutsertakan hanya variabel kepadatan penduduk (popdens) yang menunjukkan hasil yang signifikan. Sedangkan variabel porsi penduduk non-usia kerja (young dan elder) tidak menujukkan koefisien yang signifikan.

Untuk menguji Hipotesis 2, penelitian ini fokus pada perbandingan koefisien variabel dau dengan koefisien variable pad. Semua hasil pada Tabel 2 menunjukkan bahwa terjadi fenomena flypaper effect pada kebijakan belanja pemerintah provinsi. Koefisien untuk variabel dau (untuk FE sebesar 2,384 ) lebih besar dari pada koefisien variabel pad pada kolom (2) sebesar 1,801. Hasil ini membuktikan secara empiris bahwa belanja publik provinsi di Indonesia lebih responsif terhadap besaran DAU (pada literatur luar negeri biasanya dikategorikan sebagai unconditional grants) dibandingkan jumlah Penerimaan Asli Daerah.

\subsection{Model 3}

Hasil yang diperoleh pada Model 2 telah menunjukkan adanya fenomena flypaper effect pada kebijakan belanja pemerintah daerah. Namun demikian, hasil pada Model 2 belum dapat menjelaskan pertanyaan utama yang ingin dijawab oleh penelitian ini: apakah respons belanja publik searah dengan perubahan besaran variabel dau? Untuk menjawab hal tersebut uji hasil Model 3 disajikan pada Tabel 3.

Tabel 3. Hasil uji Model 3

\begin{tabular}{lccc}
\hline \multirow{2}{*}{ VARIABLES } & $(1)$ & $(2)$ & $(3)$ \\
dau & PLS & FE & RE \\
\hline & $\begin{array}{c}3.056 * \star * \\
(0.422)\end{array}$ & $\begin{array}{c}2.360 * \star * \\
(0.407)\end{array}$ & $\begin{array}{c}2.363 * \star * \\
(0.406)\end{array}$
\end{tabular}

\footnotetext{
${ }^{2}$ Penelitian oleh Kang \& Setyawan (2012) menemukan bahwa pengaruh Pendapatan Asli Daerah terhadap belanja pemerintah kabupaten/kota lebih dominan dibanding Dana Perimbangan.
} 


\begin{tabular}{|c|c|c|c|}
\hline dak & $\begin{array}{l}-0.167 \\
(0.160)\end{array}$ & $\begin{array}{c}0.149 \\
(0.111)\end{array}$ & $\begin{array}{c}0.132 \\
(0.103)\end{array}$ \\
\hline pad & $\begin{array}{l}1.677 \star \star \star \\
(0.0641)\end{array}$ & $\begin{array}{c}1.753 * * * \\
(0.102)\end{array}$ & $\begin{array}{l}1.727 * * * \\
(0.0370)\end{array}$ \\
\hline popdens & $\begin{array}{c}564,244^{* * *} \\
(115,978)\end{array}$ & $\begin{array}{c}179,639 \\
(2.25 e+06)\end{array}$ & $\begin{array}{c}447,668 * * * \\
(68,881)\end{array}$ \\
\hline young & $\begin{array}{l}1.708 e+09 \\
(1.57 e+09)\end{array}$ & $\begin{array}{r}-4.671 e+07 \\
(9.95 e+08)\end{array}$ & $\begin{array}{l}1.871 e+08 \\
(1.02 e+09)\end{array}$ \\
\hline elder & $\begin{array}{c}-6.4 e+10 * \star \\
(8.56 e+09)\end{array}$ & $\begin{array}{c}-8.628 e+10 \\
(5.37 e+10)\end{array}$ & $\begin{array}{c}-7.2 e+10 * \star \\
(2.79 e+10)\end{array}$ \\
\hline dau_int & $\begin{array}{c}0.297 \\
(4.172)\end{array}$ & $\begin{array}{l}-1.054 \\
(3.455)\end{array}$ & $\begin{array}{l}-1.297 \\
(3.065)\end{array}$ \\
\hline Constant & $\begin{array}{l}1.59 e+09 * * \\
(7.89 e+08)\end{array}$ & $\begin{array}{l}3.713 e+09 \\
(2.53 e+09)\end{array}$ & $\begin{array}{c}2.890 e+09 * * \\
(1.298 e+09)\end{array}$ \\
\hline $\begin{array}{l}\text { Obs } \\
\text { R-squared }\end{array}$ & $\begin{array}{c}336 \\
0.962\end{array}$ & $\begin{array}{c}336 \\
0.947\end{array}$ & 336 \\
\hline $\mathrm{N}$ & & 34 & 34 \\
\hline
\end{tabular}

Seperti yang dapat diperkirakan, Tabel 3 juga menunjukkan pengaruh variabel dau dan variabel pad yang signifikan terhadap pengeluaran publik. Hal ini menegaskan bahwa fasilitas umum adalah barang normal. Secara rata-rata, pemerintah daerah meningkatkan pengeluaran publik sebesar 2,3 atau 1,7 kali sebagai respons terhadap peningkatan DAU atau PAD, secara berturut-turut. Tabel 3 pun sekali lagi membuktikan adanya fenomena flypaper effect.

Beralih ke topik utama yaitu mengenai arah respons kebijakan belanja pemerintah daerah. Tabel 3 menyajikan bukti empiris bahwa tidak terdapat fenomena flypaper effect yang asimetris. Hal ini bisa dilihat dari variabel dau_int, yang merupakan interaksi antara variabel dummy dengan pertumbuhan jumlah DAU. Nilai koefisien yang negatif menunjukkan bahwa ketika penerimaan DAU mengalami penurunan, pemerintah daerah berusaha untuk meningkatkan atau setidaknya mempertahankan tingkat belanja publik. Meskipun ada indikasi mengenai flypaper effect yang asimetris, secara statistik kita tidak bisa mempercayai bahwa hal tersebut benar, bahkan dengan tingkat kepercayaan $90 \%$.

Temuan penelitian ini menunjukkan bahwa respons pengeluaran pemerintah daerah secara rata-rata searah dengan peningkatan atau pengurangan DAU. Dengan demikian tidak terbukti ada flypaper effect asimetris dan fenomena flypaper effect terindikasi beroperasi di kedua arah. Hasil ini sejalan dengan salah satu penelitian pionir di bidang ini yang dilakukan oleh Gamkhar \& Oates (1996), namun bertolak belakang dengan beberapa penelitian sesudahnya (lihat Heyndels (2001)).

\section{KESIMPULAN DAN SARAN}

Flypaper Effect disebut-sebut sebagai anomali yang paling sering dibicarakan dalam konteks federalisme fiskal. Meskipun upaya untuk menjelaskan fenomena ini sudah banyak, tetap tidak ada konsensus teoretis yang telah disepakati. Beberapa peneliti, baik pada awal pemikiran ini berkembang maupun penelitian-penelitian akhir, melaporkan bukti empiris yang berbeda. Data empiris di Amerika Serikat dan beberapa negara maju di Eropa membuktikan adanya fenomena flypaper effect. Demikian pula beberapa hasil uji empiris di Indonesia, meskipun tidak semua penelitian menghasilkan kesimpulan yang serupa.

Sebelum kami menyajikan kesimpulan dari penelitian ini, kami menyadari bahwa kelemahan utama dari penelitian ini adalah penggunaan data di level provinsi. Penggunaan data di level provinsi memungkinkan uji statistik untuk seluruh provinsi di Indonesia. Namun demikian, data pada level provinsi merupakan data agregat dari setiap kabupaten/kota yang ada di wilayah jurisdiksinya. Sehingga, hasil penelitian ini seakan-akan menyeragamkan belanja dan pendapatan daerah kabupaten/kota pada masing-masing provinsi. Padahal, penerimaan dan pengeluaran pemerintah kabupaten/kota dalam satu provinsi tentu saja bervariasi. Penggunaan data level kabupaten/kota pada penelititan yang akan datang tentunya akan lebih dapat menjelaskan topik flypaper effect di Indonesia. Tetapi tentu saja, memperoleh data variabel kontrol pada level kabupaten/kota untuk seluruh Indonesia masih menjadi permasalahan klasik penelitian di bidang studi regional.

Menggunakan data panel seluruh provinsi di Indonesia rentang periode 2010-2019, kami menguji keberadaan fenomena flypaper effect di Indonesia. Kami tidak menemukan fenomena flypaper effect ketika menggunakan model sederhana yang hanya melibatkan variabel Dana Perimbangan (secara total) dan variabel PAD. Namun, hasil yang berbeda ditemukan ketika Dana Perimbangan dibedah menjadi DAU dan DAK. Menggunakan variabel yang lebih detail, kami menemukan bukti empiris yang cukup jelas bahwa kebijakan belanja pemerintah daerah di Indonesia lebih responsif terhadap kenaikan atau penurunan DAU ketimbang kenaikan atau penurunan PAD. Artinya, fenomena flypaper effect terjadi pada kebijakan belanja publik di Indonesia.

Selain itu, kami juga menyimpulkan bahwa pemerintah daerah tidak merespons penurunan penerimaan DAU secara asimetris. Artinya, jika penerimaan DAU menurun, maka pemerintah daerah akan merespons dengan menyesuaikan belanja publik secara negatif. Hal ini mengindikasikan masih kuatnya ketergantungan pemerintah daerah terhadap dana transfer dari pemerintah pusat. Oleh karena itu, penelitian ini pemerintah pusat perlu lebih berhati-hati jika ingin mengimplementasikan kebijkaan pengetatan alokasi DAU. Kebijakan ini, terindikasi akan menurunkan belanja publik dan 
tentunya penurunan penyediaan barang publik oleh pemerintah daerah.

Sejalan dengan itu, secara tersirat juga dapat disimpulkan bahwa pendapatan pajak daerah yang menyokong PAD belum dapat mendominasi kebijakan belanja pemerintah daerah meskipun desentralisasi pajak melalui Undang-Undang Nomor 28 Tahun 2009 tentang Pajak Daerah dan Retribusi Daerah telah diinisiasi sejak tahun 2010. Pemberian kewenangan pemungutan pajak yang lebih besar terhadap pemerintah daerah mungkin dapat menjadi solusi. Tentu saja, kebijakan ini perlu memperhatikan kemampuan institusi pemerintah daerah yang ada saat ini.

\section{DAFTAR PUSTAKA (REFERENCES)}

Albuquerque, B. (2011). Fiscal institutions and public spending volatility in Europe. Economic Modelling, 28, 2544-2559. https://doi.org/doi:10. 1016/j.econmod.2011.07.018

Amalia, F. (2017). Flypaper Effect of Regional Expenditure and It's Impact to Regional Inequality in Indonesia. Signifikan: Jurnal IImu Ekonomi, 6(1), 125-138. https://doi.org/10.15408/sjie.v6i1.3293

Bailey, S. J., \& Connolly, S. (1998). The flypaper effect: Identifying areas for further research. Public Choice, Vol. 95, pp. 335-361. https://doi.org/10.1023/a:1005053921709

Bradford, D. F., \& Oates, W. E. (1971). The Economics of Political Decentralization: Towards a Predictive Theory of Intergovernmental Grants. American Economic Review, 61(2), 440-449. Retrieved from http://www.jstor.org/stable/1817026

Courant, P., Gramlich, E., \& Rubinfeld, D. (1978). The stimulative effects of intergovernmental grants: Or why money sticks where it hits. Fiscal Federalism and Grants-in-Aid, (May), 5-21. Retrieved from http://www.warreninstitute.berkeley.edu/facu Ity/rubinfeldd/Profile/publications/stimulative _effects.pdf

Fadilah, H., \& Helmayunita, N. (2020). Analisis Flypaper Effect pada Dana Alokasi Umum, Dana Alokasi Khusus, Dana Bagi Hasil, dan Pendapatan Asli daerah terhadap Belanja Daerah Provinsi di Indonesia. Jurnal Eksplorasi Akuntansi, 2(3), 3144-3159. https://doi.org/10.24036/jea.v2i3.273

Fikri, F. (2020). Flypaper effect analysis on regional expenditure in East Java Province, Indonesia. Jurnal Ekonomi \& Studi Pembangunan, 21(2). https://doi.org/10.18196/jesp.21.2.5045

Furceri, D., \& Karras, G. (2008). Business cycle volatility and country size: Evidence for a sample of OECD countries. Economics Bulletin, 5, 1-7.

Gamkhar, S. (2000). Is the response of state and local highway spending symmetric to increases and decreases in federal highway grants? Public Finance Review, 28(1), 3-25. https://doi.org/10.1177\%2F109114210002800 101

Gamkhar, S., \& Oates, W. E. (1996). Asymmetries in the response to increases and decreases in intergovernmental grants: Some empirical findings. National Tax Joural, 49(4), 501-512. Retrieved from http://www.jstor.org/stable/41789223

Gramlich, E. (1987). Federalism and Federal Deficit Reduction. National Tax Journal, 40(3), 299313. Retrieved from http://www.jstor.org/stable/41788670

Hamilton, J. H. (1986). The flypaper effect and the deadweight loss from taxation. Journal of Urban Economics, 19(2), 148-155. https://doi.org/10.1016/0094-1190(86)900367

Heyndels, B. (2001). Asymmetries in the flypaper effect: empirical evidence for the Flemish municipalities. Applied Economics, 33(10), 1329-1334.

https://doi.org/10.1080/00036840010004536

Hines, J. R., \& Thaler, R. H. (1995). Anomalies the flypaper effect. Journal of Economic Perspectives, 9(4), 217-226. https://doi.org/10.1257/jep.9.4.217

Inayati, N. I., \& Setiawan, D. (2018). Fenomena Flypaper Effect Pada Belanja Daerah Kabupaten/Kota Di Indonesia. EKUITAS (Jurnal Ekonomi Dan Keuangan), 1(2), 220-239. https://doi.org/10.24034/j25485024.y2017.v1. i2.2062

Inman, R. P. (2016). The Flypaper Effect. International Tax and Public Finance Tax Public Finance, (23), 114-139. https://doi.org/10.3386/w14579

Kang, Y., \& Setyawan, D. (2012). Intergovernmental transfer and the Flypaper Effect-evidence from municipalities/regencies in Indonesia." KDI School of Pub Policy \& Management Paper 1206 (2012). KDI School of Pub Policy \& Management Paper, (12-06). Retrieved from http://www.kdischool.ac.kr/new/eng/faculty/ working.jsp

Kuncoro, H. (2007). Fenomena Flypaper Effect Pada Kinerja Keuangan Pemerintah. Simposium Nasional Akuntansi $X$, (juli).

McGuire, M. (1975). An econometric model of federal grants and local fiscal response. In W. E. Oates (Ed.), Financing the new federalism (pp. 115139). Baltimore: John Hopkins University Press.

Rudi, M. (2018). Flypaper Effect of Regional Expenditures in Yogyakarta. Shirkah: Journal of 
Economics and Business, 2(3). https://doi.org/10.22515/shirkah.v2i3.168

Sacchi, A., \& Salotti, S. (2017). The influence of decentralized taxes and intergovernmental grants on local spending volatility. Regional Studies, 51(4), 507-522. https://doi.org/10.1080/00343404.2015.1111 512

Solikin, A. (2016). Analisis Flypaper Effect Pada Pengujian Pengaruh Dana Alokasi Umum (DAU), Pendapatan Asli Daerah (PAD), Dan Sisa Lebih Penghitungan Anggaran (SiLPA) Terhadap Belanja Pemerintah Daerah Di Indonesia (Studi Tahun 2012-2014). Jurnal Akuntansi Dan Bisnis, 16(1), https://doi.org/10.20961/jab.v16i1.187

Stine, W. F. (1994). Is local government revenue response to fed-eral aid symmetrical? Evidence from Pennsylvania County Governments in an Era of Retrenchment. National Tax Journal, 57(4), 799-816. Retrieved from http://www.jstor.org/stable/41789109

Utami, S., \& Iskandar, D. D. (2020). Flypaper effect terhadap determinan belanja daerah dan determinan pendapatan asli daerah pada 34 provinsi di Indonesia tahun 2013-2018 (two stage least square). Jurnal Dinamika Ekonomi Pembangunan, 3(3), 202-218. https://doi.org/10.14710/jdep.3.3.\%p

Yacoub, Y., \& Lestari, N. (2019). Flypaper Effect in Indonesia: The Case of Kalimantan. J. Fin. Bank Review, 4(4), 116-121. https://doi.org/10.35609/jfbr.2019.4.4(1) 